\title{
WOMEN IN THE BOARDROOM: A REAPPRAISAL
}

\section{Frank CARRIGAN*}

The purpose of this article is to explore the economic logic of the market in relation to the gender composition of Australian boardrooms. It argues that the benefits that could flow from more women occupying senior positions in Australian corporations will not overcome the laws of the market and the inherent competitive pressures that determine the trajectory of corporations. Placing more women on corporate boards must be supported as a matter of equity. However, it is unlikely that such a democratisation of corporations will impact on the internal structures that foster the broader inequality that is the taproot of the system and constitutes the day to day relationships of business.

\section{INTRODUCTION}

In an Australian law journal article, 'Regulating for Women on Corporate Boards: Polycentric Governance in Australia', ${ }^{1}$ Vijaya Nagarajan explores the case for advancing the role of women on boards. Her article focuses on pinpointing mechanisms that need to be more efficacious if gender diversity at the apex of the corporate form is to be optimised. In effect, she suggests 'using diverse methods to change business norms to move slowly to our goal'.

In essence, Nagarajan undertakes an enquiry into regulatory instruments that have the potential capacity to increase the participation of women on corporate boards if only they were better implemented. Her objective is to list mechanisms that could assist in achieving a more egalitarian corporate gender order, and the regulatory forces that are best equipped to implement gender diversity at the top of the corporate tree. Nagarajan proceeds with caution but her exploration of the regulatory kit that has the capacity to ameliorate corporate democratic deficits operates in an environment where in her own

\footnotetext{
* LLB (UNSW), PhD (Sydney), Senior Lecturer, Law School, Macquarie University.

1 (2011) 39(2) Federal Law Review 255.

${ }^{2}$ Ibid 279.
} 
words there is a 'widespread acknowledgment that the inadequate representation of women on corporate boards was a problem that should be addressed' ${ }^{3}$

This article has a different conceptual framework to the one utilised by Nagarajan. It places the spotlight on some of the key mechanisms that she explores and argues that, even if they were made more effective, the corporate gender issue would still confront contradictions. This work will act as a counterpoint to what Nagarajan terms 'the regulatory game in Australia'. ${ }^{4}$ It will excavate the foundations of the corporate economy, and propose that boosting regulatory tools offers at best a partial way forward for dealing with the inadequate role of women in the corporate suites of Australia. At various points this work will develop a parallel conceptual structure of the modern corporation that goes beyond positing more women on corporate boards as the way forward for what Nagarajan describes as 'moving the corporate board to a more democratic representation of societies' diversity'. 5

The role of gender and the structure of corporate boards is not just an Australiabased issue. It is, as Nagarajan's article notes, a topic being pursued in a number of countries. ${ }^{6}$ Nagarajan's focus on the gender gap at the corporate board level provides a welcome platform to interrogate the crucial issue of women in the boardroom.

This article will espouse the view that the gender composition of corporate boards is secondary in a modern corporate capitalist economy to the quest to recruit those who possess the individual qualities required to maximise profits. Those at the commanding heights of the economy are driven, regardless of gender, to maximise their own skill set and optimise the business's productivity by utilising the resources of the business with the greatest possible efficiency. In order to understand the deep-seated causes of events in a market economy it has to be remembered 'that the characters who appear on the economic stage are merely personifications of economic relations; it is as the bearers of these economic relations that they come into contact with each other' ${ }^{7}$ To maximise profit and to remain in business are the sole goals of capitalist enterprises and these aims are dependent on enterprises utilising factors of production in a way that will produce the most efficient level of output. ${ }^{8}$ In effect, the systemic logic

\footnotetext{
${ }^{3}$ Ibid.

${ }^{4}$ Ibid 255 .

${ }^{5}$ Ibid 257.

${ }^{6}$ Ibid 264.

${ }^{7}$ Karl Marx, Capital (Penguin, 1979) vol 1, 179.

${ }^{8}$ Joel Bakan, The Corporation: The Pathological Pursuit of Profit and Power (Constable, 2004) 28.
} 
of the market laws of capitalism eclipses any factors other than talent in accumulating capital in determining those equipped to become company directors.

The liberal utilitarian view of market society ${ }^{9}$ relies upon the assumption that the sovereign decisions of individuals operate in the context of an open market of freely contracting adults, which maximises an efficient allocation of resources. Under this model the process of individual rational calculation is gender neutral in the sense that the gender identity of the participants impacts not one jot on the optimum allocation of resources. ${ }^{10}$ The market is only explicable by reference to the goals and actions of rational utility-maximising individuals. ${ }^{11}$ Capitalist entrepreneurs function under the compulsion of a set of austere market principles oriented to maximising profit that operate in a manner indifferent to the gender of individuals. ${ }^{12}$

The competitive accumulation process that is the keystone of capitalism dictates that each company must turn the screw on its workers and achieve output per worker equal to or higher than that of its competitors and with no more waste, or end up in liquidation. ${ }^{13}$ It is the skill level of individuals of either gender that is the key to a company's success, and particularly their ability to optimise productivity and drive down labour costs per unit of production that is the litmus test for the capacity to operate at the apex of a corporation. The primary dynamic of capitalism is the extraction of surplus value from wage labourers ${ }^{14}$ and, if a woman has the skills to maximise economic efficiency and becomes a business executive, her gender is secondary to the fact that she is, by virtue of her commercial role, a participant in economic relations based on power.

Regardless of the business executive's individual approach to social policy, she is an integral part of the dominant class and is therefore compelled to operate in accordance with the profitmaking logic of the capitalist system. Her privileged class location makes her a bourgeois woman, endowed with the social power to extract surplus value from the sweat of a worker. Female directors are on a different social plane to women employees who are paid a wage that is less than the value they generate during the course of a working

\footnotetext{
${ }^{9}$ Milton Friedman, Capitalism and Freedom (The University of Chicago Press, 1982) 13.

${ }^{10}$ Cento G Veljanovski, Economic Principles of Law (Cambridge University Press, 2007) 32.

${ }^{11}$ Ibid 37.

${ }^{12}$ Francis Green and Bob Sutcliffe, The Profit System: The Economics of Capitalism (Penguin, 1987) 6.

${ }^{13}$ Marx, above n 7, 899.

${ }^{14}$ Ibid 742.
} 
day. ${ }^{15}$ The stratospheric income of directors of either gender in the largest and most successful enterprises is accounted for by workers not receiving the full value of their labour.

A critical spirit and the courage to boldly take a contrarian position on issues are prerequisites for life at the apex of the corporate pyramid. Boosting boardroom female numbers is a laudable aim and one that progressive thinkers must support. Nagarajan is right to state that 'there is widespread acceptance that companies should have more women on their boards' ${ }^{16}$ However, the full implications of achieving that goal must be considered. Whatever gender one belongs to is immaterial to life at the commanding heights of a corporation. In a nutshell, an executive is judged according to the sole yardstick of his or her ability to maximise earnings per share on behalf of investor. Only those administrators of capital who achieve an efficient allocation of economic resources and maximise returns in their industry will keep investors happy, and thus stay in the corporate limelight. Adding maximum value to corporate assets is the prime objective of those in the cockpit of a corporation, and the achievement of that goal depends on variables that have nothing to do with gender.

The focal point of a corporation is to maximise the profits of the shareholders who own the capital, and boosting the participation of women at the level of the corporate board for any reason other than profitability runs counter to its purpose. Capital cares only about the colour of money, not the gender of the administrators of the system. As Bakan notes: 'The corporation, like the psychopathic personality it resembles, is programmed to exploit others for profit. That is its only legitimate mandate. ${ }^{17}$

A crucial barrier to gender diversity is the structure of the corporation and the obstacles it places in the way of any type of social engineering. For example, Bakan argues that corporate social responsibility is illegal. As he puts it: 'managers and directors have a legal duty to put shareholders' interests above all others and no legal authority to serve any other interest. ${ }^{18}$ When the sole mandate of a corporation is to maximise profits any tinkering with its profit objective is shot through with contradictions. The reluctance of a number of powerful states to legislate for gender diversity despite 'widespread acceptance' of the notion pinpoints the role that capital imperatives play in the

\footnotetext{
${ }^{15}$ Ibid 342.

${ }^{16}$ Nagarajan, above $n$ 1, 262.

${ }^{17}$ Bakan, above n 8, 69 .

${ }^{18}$ Ibid 36.
} 
modern corporation. Public pressure is diminishing the sway of capital and reducing the gender gap but it is a slow process.

It may be the case that eventually the social justice argument for gender balance in boardrooms will everywhere override the profit imperative. But, given the legal duties of privileging shareholder interests imposed upon directors by corporate law, the whole issue of gender diversity is problematic. Hadden notes: 'Company law is about capitalism. It provides the formal legal structure necessary to the operation of the capitalist system.' ${ }^{19}$ Corporate law is inextricably intertwined with the profit system.

The measure of success in a market economy is nothing other than the capacity to effectively pursue maximum profit. The iron law of economic competition compels every firm to cut costs, and be price competitive and optimise profit, or fall by the wayside. The economic downside of putting gender diversity or, for example, the quest for corporate responsibility in the vanguard when making appointments to corporate boards needs to be examined. Equitable factors are extraneous to the running of a capitalist corporate economy.

The first part of this article examines the backdrop to what Nagarajan terms 'tackling the gender gap on the boards of publicly listed companies'. ${ }^{20}$ Nagarajan's article is a reminder that pressure is building on the corporate front as progress towards gender diversity has been made in a number of countries. Norway, Sweden, the Netherlands, Italy and France have 'all introduced legislation requiring gender quotas'. ${ }^{21}$ The British government is contemplating imposing quotas to speed up the appointment of women directors. ${ }^{22}$ At the same time, in the United States, with the percentage of women on boards at 12.6 per cent, the voluntary approach to boosting numbers is being promoted. ${ }^{23}$ Change is slowly happening but some powerful capitalist societies are still resistant to expansive movement.

\footnotetext{
${ }^{19}$ Tom Hadden, Company Law and Capitalism (Weidenfeld and Nicolson, 1972) 3.

${ }^{20}$ Nagarajan, above $\mathrm{n} 1,255$.

${ }^{21}$ Sally Wheeler, 'Independent Directors and Corporate Governance' (2012) 27(2) Australian Journal of Corporate Law 180.

${ }^{22}$ Andrew Grice, 'Vince Cable tells City: Put more women in the boardroom before we force you' The Independent (online), 10 April 2013 <http://www.independent.co.uk/news/uk/ politics/vince-cable-tells-city-put-more-women-in-the-boardroom-before-we-force-you-8566 604.html >.

${ }^{23}$ Paul Hodgson, 'Women on Boards: The Good News, There are More. The Bad News, Not That Many' (3 August 2012) Forbes <http://www.forbes.com/sites/paulhodgson/2012/03/08/ women-on-boards-the-good-news-there-are-more-the-bad-news-not-that-many/> .
} 
The article then undertakes an examination of some of the thinking underlying the push for board gender diversity before presenting a series of case studies that scrutinise the history of a number of female directors who scaled the corporate heights. In this part of the work it is suggested that for the bulk of female wage-workers domination and subordination would continue to be the staple of their lives regardless of the gender composition of the corporate boardroom. This point which forms part of this article's framework of analysis of corporate power will, along with other factors, be reinforced in the course of the article.

\section{Everything Old Is New Again}

In her article, Nagarajan notes that women hold 10.9 per cent of the directorships available in the leading 200 Australian publicly listed companies. ${ }^{24}$ She notes reasons that are advanced to redress the issue of the gender gap in the boardroom and describes them as being constitutive of:

a more democratic representation of societies' diversity; improved decisionmaking by increasing the range of views, values and experiences represented; better corporate profitability; and finally an enhanced corporate image for shareholders, employees and consumers. ${ }^{25}$

Nagarajan puts forward a methodology which is termed 'polycentric governance' as the means of rectifying the gender deficit at the peak of the corporation. This multifaceted approach to reform involves the state collaborating with a myriad of private bodies in order to secure their compliance with the objective of increasing the participation of women on corporate boards. ${ }^{26}$ Parties that are already engaged in a relationship with government to increase the representation of women on boards are identified by Nagarajan: they include Woolworths, Westpac, the Australian Institute of Company Directors, the Business Council of Australia and the Australian Stock Exchange. ${ }^{27}$ According to Nagarajan, 'the notion of the state being at the centre of regulation has given way to a polycentred notion of governance where a range of actors are involved in different facets of the regulatory regime'. ${ }^{28}$

\footnotetext{
${ }^{24}$ Nagarajan, above n 1, 255.

${ }^{25}$ Ibid 257.

${ }^{26}$ Ibid 279.

${ }^{27}$ Ibid $258,270$.

${ }^{28}$ Ibid 256.
} 
Nagarajan describes how power in corporate Australia is shared among a constellation of forces. In effect she describes a pluralist interpretation of power. Her polycentric vision of power sees power as diffused and it has been depicted as creating a context where no 'single set of interests is dominant'. ${ }^{29}$ Polycentric governance according to Nagarajan produces a situation where social policy 'is not dominated by one specific body such as a government funded regulator. Rather than the government taking control to implement and enforce quotas, it is multiple non-state actors that are facilitating this' ${ }^{30} \mathrm{In}$ effect, the liberal notion of atomistic and independent centres of power driving governance practices in a market society is of prime importance. Nagarajan's analysis of key ideas is, however, thinly drawn. The concept of polycentric governance, for example, is left underdeveloped. No link is drawn between the interaction of the corporate oligarchy and the state. Private organisations and state structures are not portrayed as a unified entity always working hand in hand in shaping policy, with the state as an overarching body responsible for assisting in reproducing the hegemonic role of capital. The issue of whether polycentric governance is a diffused power model, and thus pluralism by another name, escapes Nagarajan's field of enquiry.

Pluralist theory was in vogue in the 1960s and 1970s and was based on the suggestion that the epicentre of power in contemporary market societies is not to be found in any particular class but is divided between elite bodies such as business, the church, parliament, the army and so forth. ${ }^{31}$ The fact that economic power translates into the establishment of a ruling class that wields social and political power is beyond the pluralist interpretation of power.

Whilst Nagarajan describes a range of discrete actors lobbying for gender equality in the boardroom, she renders invisible the fact that these groups are an interlocking body that utilises the state to promote the collective viewpoint of a particular class. Those calling for the reshaping of corporate boardrooms are an integrated group. The monopolistic business interests in banking and industry typified by the Woolworths and Westpacs of Australia that Nagarajan depicts $^{32}$ as calling for gender reform at the apex of the corporation are linked to lobby groups such as the Business Council of Australia and the Australian Institute of Company Directors ${ }^{33}$ that are also engaged in efforts to increase the

\footnotetext{
${ }^{29}$ John Westergaard, 'Sociology: The Myth of Classlessness' in Robin Blackburn (ed), Ideology in Social Science: Readings in Critical Social Theory (Fontana, 1972) 119, 139.

${ }^{30}$ Nagarajan, above n 1, 256.

${ }^{31}$ Robin Blackburn, 'A Brief Guide to Bourgeois Ideology,' in Alexander Cockburn and Robin Blackburn (eds), Student Power: Problems, Diagnosis, Action (Penguin, 1969) 163, 189.

${ }^{32}$ Nagarajan, above n 1, 258, 270.

${ }^{33}$ Ibid 270.
} 
participation of women in the boardroom. It would be implausible to construe the Australian Institute of Company Directors and the Business Council of Australia as competing interest groups. Although Nagarajan does not pursue that line, her pluralist model, by omitting the crucial point that corporations and their lobby groups combine to create an integrated ruling class, fails to shed more than a partial light on the nature of the forces aiming to recruit more women into the boardrooms of Australia.

Kuhn and O'Lincoln have cogently depicted the contours of the ruling elite that combine wealth, ownership and power in corporate Australia. ${ }^{34}$ Overseas studies highlight a similar phenomenon to the one illuminated by thinkers such as Kuhn and O'Lincoln..$^{35}$ In the US, there is a long history of business interest groups translating their economic power into political and social power and thereby utilising their position to skew legislation towards serving narrow economic interests. ${ }^{36}$ In Australia the way in which business interest groups order government policy to suit their needs was evident in the way climate change has been addressed. Guy Pearse was a Liberal party member, lobbyist and a Howard government advisor before he produced an informative book depicting how the government of which he was an inside member allowed its climate policy to be written by the biggest corporate polluters and the lobbyists they funded. ${ }^{37}$

The pluralist model collapses under the weight of the existence of monopolies that utilise the state to protect the extant social system based on concentrated private ownership of capital. ${ }^{38}$ Monopolies, through a number of channels, are engaged in reproducing social and power relationships, and they perform this function in league with state organs. Any talk, under these conditions, about the state devolving regulatory doctrine to a farrago of atomistic agents is misleading. It is an unrealistic strategy when the reality is that the economic clout of big business is translated into social and political power and the state operates to reproduce its hegemony.

\footnotetext{
${ }^{34}$ Tom O'Lincoln, 'Wealth, Ownership and Power: The Ruling Class' in Rick Kuhn and Tom O'Lincoln (eds), Class \& Class Conflict in Australia (Longman, 1996) 5. Also Rick Kuhn, 'Illusions of Equality: The Capitalist State' in Rick Kuhn (ed), Class and Struggle in Australia (Pearson Longman, 2005) 40.

${ }^{35}$ Daniel A Farber and Philip P Frickey, Law and Public Choice: A Critical Introduction (University of Chicago Press, 1991) 17.

${ }^{36}$ Ibid 19.

${ }^{37}$ Guy Pearse, High and Dry: John Howard, Climate Change and the Selling of Australia's Future (Penguin Group, 2007) 20, 152.

${ }^{38}$ Paul Mattick, 'Economics, Politics and the Age of Inflation' (1978) 8(3) International Journal of Politics 80.
} 
Nagarajan makes a reference to the state at a few places in her article. But she limits her discussion of the state to statements about its potential to steer business norms towards compliance with achieving better gender outcomes at the board level ${ }^{39}$ Nagarajan's atomistic approach to power leads her to be at best ambiguous about the interrelationship between the state and business. She states: 'I am using polycentric governance here because regulation in this space is emanating from many centres, involving non-state and state actors who may be acting independently or in concert. ${ }^{40}$ There is an absence in her article of a searching analysis of the nature and function of the state in a capitalist society.

The pact between capital and the state is aimed at maintaining the economic order. ${ }^{41}$ As Kuhn notes: 'The decisions of members of the capitalist class have huge effects, because the productive resources and hierarchies they control give them power. ${ }^{42}$ Quite simply, the personnel of the state apparatuses owe their allegiance to the upper echelons of the business class and not to a diffused set of interests. A pluralist model is an abstraction that mystifies the concentrated nature of power in a society ruled by corporations where the sovereign principle is the ownership of private property. ${ }^{43}$ Speaking about 'many regulatory centres' ${ }^{44}$ entails applying an eclectic set of selection criteria that distracts attention from the capitalist class and its key role along with the state organisations that it dominates in setting the agenda for dealing with the gender gap in business ranks.

Policy on the gender composition of corporate boards is something that those at the pinnacle of the economy and their myriad agencies will guide. The lack of a concerted view on the desired level of women in the boardroom within corporate Australia highlights the fact that, at this moment in history, there is no common view within the ranks of the economic elite on prioritising this issue. There is no insuperable barrier stopping an adequate representation of women in the boardroom. The fact that various states are moving on the issue is evidence that equality at board level is capable of being achieved by capitalism. Meiksins Wood makes the point that "capitalist exploitation is not inextricably linked with extra-economic, juridical or political identities,

\footnotetext{
${ }^{39}$ Nagarajan, above n 1, 257, 276, 279.

${ }^{40}$ Ibid 263.

${ }^{41}$ Ralph Miliband, The State in Capitalist Society (Quartet Books, 1973) 7. See also Bob Jessop, The Capitalist State: Marxist Theories and Methods (Martin Robertson, 1983) 30.

${ }^{42}$ Kuhn, above n 34, 41.

${ }^{43}$ Ralph Miliband, above n 41, 4. See also Joseph A Camilleri and Jim Falk, The End of Sovereignty? The Politics of a Shrinking and Fragmenting World (Edward Elgar, 1992) 23.

${ }^{44}$ Nagarajan above n 1, 279.
} 
inequalities or differences' ${ }^{45}$ In the final analysis all that matters to capital is unrestricted access to the wage labour that produces profit. As Marx put it, 'the most fundamental right under the law of capital is the equal exploitation of labour power by all capitalists'. ${ }^{46}$

Those members of the economic elite and their state allies leading the charge to bolster the ranks of female directors will eventually carry the day. This is because recruiting the best brains from any gender to fill the ranks of corporate directors follows the logic of capital. The economy is based on profit maximisation and it is flexible enough to overcome resistance to discarding types of oppression that impede money-making and capital accumulation. ${ }^{47}$ Change in the leading personnel at the peak of capitalist enterprise has been one of the hallmarks of capitalist history. ${ }^{48}$ Thus more women corporate directors will be appointed and this will be viewed as part of the evolution of the system. The decisive issue is whether a profit system will operate any differently with women at the corporate helm.

The elimination of gender inequalities in the corporate boardroom would at best produce a limited form of equality that would pose no threat to the centralisation of corporate power. The extraction of surplus value from wage labourers would continue even as the corporate inner circle was expanded by more female directors. The bulk of female wage-workers would continue toiling for a living wage regardless of the gender of corporate bosses. It may well be the case that a boost in female participation on corporate boards would enhance democracy, narrow the gender gap and foster a climate for a more inclusive corporate governance and higher profitability. These are arguments listed by Nagarajan. ${ }^{49}$ But the boost in democracy would only benefit a small fraction of women who would join the capitalist class, and any higher profits would be channelled towards shareholders.

What needs to be done is to look beyond the political surface and anatomise the economic and social substance of corporations within which polycentric governance operates when considering increasing the participation of women on boards.

\footnotetext{
45 Ellen Meiksins Wood, Democracy against Capitalism: Reviewing Historical Materialism (Cambridge University Press, 1995) 266.

${ }^{46}$ Marx, above $\mathrm{n} 7,405$.

${ }^{47}$ Ibid 65.

${ }^{48}$ Ernest Mandel, Marxist Economic Theory (Merlin Press, 1977) 539.

${ }^{49}$ Nagarajan, above n 1, 257.
} 
Whether ameliorating the corporate gender gap to benefit bourgeois women would alter the dynamics of the corporation and the nature of society is of crucial importance. Female directors are members of the ruling class and, if their entry to the inner circle is to be expanded this may well end up providing ideological cover for a global system grappling with stratospheric inequalities. The success of the women who climb to the summit of the corporation will be utilised by the corporate media to deflect attention from the interaction of gender and class and the structural forces that generate ongoing inequality for the majority of women in the workforce. In the context of corporations, the issue of equal opportunity being used to drive change at the apex of the corporation is a thorny one that requires further examination.

\section{The View Beyond the Surface}

This section of the article implicitly critiques pluralist or polycentric frameworks of analysis. It examines the functioning of coercive structures that are at the heart of the corporate economy, and the sombre and intractable reality that underpins the mechanisms of the capitalist mode of production.

Equal opportunity in a capitalist society is a problematic issue. What can be lost sight of is that an equality ethos is already a cornerstone of a market society. Formal equality exists between the buyers and sellers of labour hours. Contract law ensures that the wage contract creates formal equals, and excludes distinctions of a juridical or political sort. Under capitalism there is an absence of bondage to a feudal lord. Liberal individuals are already sovereign over themselves, their interests and property. Equality on the juridical and political planes is at a level far higher than it was in past socioeconomic forms. ${ }^{50}$

Yet the equality of opportunity assured in the juridical and political spheres of liberal societies is matched by significant economic inequalities and this is the empirical basis for speaking of formal equality. The burgeoning of female directors will not change the ownership structure of the modern corporation or its fundamental logic that has led to 85 individuals worldwide amassing as much wealth as the poorest half of the world. ${ }^{51}$ Formal equality is only a component part of the ensemble of social relations. Fundamentally, people in market economies personify economic relations and this phenomenon shapes

\footnotetext{
${ }^{50}$ Wood, above $\mathrm{n}$ 45, 266.

${ }^{51}$ Graeme Wearden, Oxfam: 85 Richest People as Wealthy as Poorest Half of the World (20 January 2014) The Guardian <http://www.theguardian.com/business/2014/jan/20/oxfam-85richest-people-half-of-the-world>.
} 
how they connect with each other ${ }^{52}$ Legal forms obscure the deep social and economic content expressed by social relations of production. A labour contract, for example, expresses a bargain struck by two legal equals, but what this masks is that the selling of labour hours is the source of money-making and the accumulation of capital for corporate capital. Understanding the difference between the appearance of things and the essential relations of economic life is the key to understanding how boosting female participation at the board level will not produce a more democratic society or an enhanced corporate image.

Liberalism is a contradictory philosophy because, while it celebrates the precepts of democracy and equality, it simultaneously extends the dominance of those with economic power. ${ }^{53}$ The hallmark of liberalism is its pervasive individualism but this doctrine shrivels in an age of towering corporations that produce oligarchs of capital and the concentration of economic power. The economic hegemony of corporations brings in its wake the social and political leadership of the ruling economic class.

The wages system is at the epicentre of corporate life. From a juridical point of view, the wage contract is a reciprocal relationship that involves workers voluntarily selling their labour power. This is an exchange relation characterised by equality and freedom, ${ }^{54}$ yet, just below the surface, coercion operates. This coercion represents the underside of liberalism and the corporation. For beyond the parameters of the exercise of choice that contract law exalts, the worker relinquishes property rights over labour power, the direction of work and the product of labour. ${ }^{55}$

The wages system establishes what Marx termed 'the silent compulsion of economic relations and sets the seal on the domination of the capitalist over the worker'. ${ }^{56}$ It is the fundamental economic relationship in a market society and it creates the basis, as Adam Smith noted, for the exploitation of labour. ${ }^{57}$ Smith pointed out that profit is based on workers producing more in value than they are paid. This operates behind the façade of free contract and juridical equality.

\footnotetext{
${ }^{52}$ Marx, above n 7, 179.

${ }^{53}$ Richard Lichtman, Essays in Critical Social Theory: Toward a Marxist Critique of Liberal Ideology (Peter Land Publishers Inc, 1993) 150; Domenico Losurdo, Liberalism: A Counter History (Verso, 2011) 309.

${ }^{54}$ David Harvey, The Limits to Capital (Basil Blackwell, 1984) 28.

${ }^{55}$ Michael A Lebowitz, Following Marx: Method, Critique and Crisis (Haymarket Books, 2009) 50.

${ }^{56}$ Marx, above, n 7, 899.

${ }^{57}$ Ronald L Meek, Smith, Marx, \& After: Ten Essays in the Development of Economic Thought (Chapman \& Hall, 1977) 7.
} 
It is the hidden abode of corporations, and every shareholder and director, regardless of gender, benefits from the alchemy that occurs when formal equality morphs into substantive inequality - for they are privileged benefactors of economic relations. Shareholders and directors gain from the underlying magic of market relations - what Smith termed the 'profit deducted from employees' ${ }^{58}$ In the final analysis, corporations render freedom of contract an illusion.

Once corporations sell commodities on the market, they realise sums of capital greater than the cost of the wage labour they have employed, and this is the basis of Smith's profit thesis. An increase in female directors will fail to make an impact on the laws of the market that are based on the limitless drive for profits. The laws of the market operate irrespective of gender.

Therefore, programs to achieve greater representation of women on corporate boards will strengthen the position of a few privileged women, but will have negligible impact beyond the apex of corporate pyramids. Male and female executives will share stellar remunerative packages, but the position of male and female wage labourers will not be improved. The existence of wage labour has a deleterious impact on issues such as equality, justice and fairness whilst disproportionately affecting women workers who congregate in low wage jobs. The economic oppression of the many will continue unabated as the corporate hierarchy is filled out with more women.

A recent study in the UK found that three times more young women were stuck in low paid and low skilled jobs than was the case twenty years ago ${ }^{59}$ There is a gulf that divides bourgeois and working class women and their different roles in the class structure. The class disparities in the modern corporation highlight the limits of capitalist democracy. Moreover, even those women who break through the glass ceiling by climbing the corporate ladder, can find that their tenure of high office is limited by inexorable forces that shape their fate. Just as male corporate chieftains will be forced to resign if profits slide, their female counterparts will be bound by the same rules of capital. The experiences of three women who have scaled the corporate heights and been the beneficiaries of economic largesse illuminate the precarious life of those at the apex of the corporate pyramid. It is a worthwhile sociological exercise to consider the sort of environment that awaits those female executives that would increasingly take their place on boards if schemes to improve regulatory mechanisms were more

\footnotetext{
${ }^{58}$ Ibid. See also Adam Smith, The Wealth of Nations (Penguin, 1986) 134.

${ }^{59}$ Press Association, More Young Women Trapped in Low-Paid, Low-Skilled Jobs (1 November 2013) The Guardian <http://www.theguardian.com/business/2013/nov/01/youngwomen-trapped-low-paid-skilled-jobs $>$.
} 
effective. The studies that follow pinpoint the harsh reality of life at the top of the corporate ladder.

\section{A The Case of Sue Morphet, Pacific Brands}

In 2005, an Australian clothing company producing a range of iconic underwear and hosiery products (Pacific Brands) was engaged in a systematic endeavour to lift productivity, raise profits and cut costs. A journalist on a tour of the Pacific Brands', Wentworthville factory in Sydney's west noted that 'it is clear they have tried to squeeze out every efficiency from the production process' ${ }^{60}$ Pacific Brands was utilising computer technology to quicken the pace of knitting and dyeing machines producing underwear, t-shirts and swimwear. ${ }^{61}$ The motor force behind the attempt to lift the output per hour of every worker was clear to the Pacific Brands hierarchy. This was part and parcel of a campaign to achieve the "sort of cost control and efficiency that the company has had to refine to survive against the behemoth that is the Chinese manufacturing sector'. ${ }^{62}$ In brief, Pacific Brands was involved in a desperate struggle to match or eclipse Chinese productivity levels and failure to do so would ensure unpalatable options.

The Pacific Brands head of manufacturing was blunt. If there was any slowdown in innovation, reduction of costs or slackening of the speed of production, the Pacific Brands local manufacturing base would close. ${ }^{63}$ The head of manufacturing was adamant 'that the economics of manufacturing in Australia are constantly reassessed by the company as competition intensifies and Chinese manufacturing standards improve'. ${ }^{64}$ In January 2008, Sue Morphet was anointed the chief executive of Pacific Brands. Within a year she and the rest of the board had come to the conclusion that there was 'no longterm sustainable advantage from local manufacturing', and that 'efforts to make (its facilities) cost efficient (were) no longer relevant' ${ }^{65}$ Their belief was that domestic manufacturing was uncompetitive; and that, as a result, production was to be outsourced to China, making 1850 Australian workers redundant. ${ }^{66}$

\footnotetext{
60 G Newman, 'Flex and Flexibility' 33 The Australian (Sydney, 22 October 2005) <https://mail.google.com/a/mq.edu.au>.

61 Ibid.

62 Ibid.

63 Ibid.

64 Ibid.

65 Ari Sharp and Chris Zappone, 'West End Factory to Close as Bonds Goes Offshore' Brisbane Times (online), 25 February $2009<\mathrm{http}$ ///www.brisbanetimes.com.au/articles/2009/02/25/ 1235237708475.html>.

66 Ibid.
} 
There had been a profit slump, and the cost saving from shifting production off shore and axing local manufacturing was estimated at $\mathrm{A} \$ 150$ million a year. ${ }^{67}$

In the period prior to Pacific Brands announcing its restructure sacking its largely migrant female workforce, Morphet's annual package rose from $\mathrm{A} \$ 685775$ to $\mathrm{A} \$ 1.86$ million. ${ }^{68}$ This sum included incentive payments for axing jobs. ${ }^{69}$

By 2011, the Pacific Brands share price was languishing as new problems surfaced. The launch of the Spanish multinational Zara chain in Australia impacted on Pacific Brands' grip on the youth market and retailers such as Myer were circumventing Pacific Brands by going directly to Chinese manufacturers in order to get cheaper house-brand merchandise. ${ }^{70}$ In 2012, Morphet fell on her sword as the annual net loss skyrocketed to $\mathrm{A} \$ 450.7$ million and sales fell by 18 per cent. ${ }^{71}$ Morphet was blamed for choosing poor suppliers in China and not stemming the resultant drop in quality and sales of key brands such as Bonds and Holeproof. ${ }^{72}$

\section{B The Case of Cynthia Carroll, Anglo American}

In March 2007, Cynthia Carroll became the chief executive of one of the world's top five mining multinationals, Anglo American, which operates a portfolio of global mines. Many of the issues that beset Morphet also enveloped Carroll. Chief executives of either gender are bound by the logic of a capitalist system that operates according to its relentless profitmaking goals. On a daily basis, every capitalist manager must achieve a return on capital that is at least average for the industry or watch their firm perish. Thus, all chief executives constantly confront the potential liquidation of their business and career.

\footnotetext{
${ }^{67}$ Ibid.

${ }^{68}$ Australian Associated Press, 'Pacific Brands Sacks 1800 while Bosses Pocket Pay Rises' The Australian (online), 27 February $2009<\mathrm{http} / / / \mathrm{www}$.theaustralian.com.au/news/nation/pacificdefends-170pc-execs-pay-rise/story-e6frg6nf-1111118982689>.

${ }^{69}$ Ibid.

${ }^{70}$ Ben Butler and Mark Hawthorne, 'Rag Trader Stretched at the Seams' Sydney Morning Herald (online), 11 June $2011<\mathrm{http} / / / \mathrm{www} . s m h . c o m . a u /$ business/rag-trader-stretched-at-the-seams20110610-1fwy8.html $>$.

${ }^{71}$ Adele Ferguson, 'PacBrands Battles to Avoid a Billabong Repeat' Sydney Morning Herald (online), 22 August $2012<$ http://www.smh.com.au/business/earnings-season/pacbrandsbattles-to-avoid-a-billabong-repeat-20120822-24lr7.html>.

${ }^{72}$ Ibid.
} 
Carroll and her female peers are no different from their male counterparts regarding the life and death struggle that is waged every day.

In Carroll's case, in order to streamline the cost structure and boost the productivity of Anglo American, she forced 26000 compulsory redundancies but still failed to reach the profit levels deemed necessary by shareholders. ${ }^{73} \mathrm{By}$ 2012, cost blowouts on new projects and missed opportunities led to a loss of a third of Anglo's value and a plummeting share price. ${ }^{74}$ One of Anglo's largest shareholders lost patience and 'criticised Carroll's 'poor decision making' calling for her 'swift replacement' ${ }^{75}$ The economic stakeholders of a corporation trump administrative figures such as Carroll and 'after months of intense pressure from shareholders' she stepped down in October 2012. ${ }^{76}$ Some of her defining problems were replicated by Marissa Mayer.

\section{The Case of Marissa Mayer, Yahoo!}

In 2012 the technology giant Yahoo! installed Marissa Mayer as its CEO. As the experience of Morphet and Carroll illuminates, capitalism is intrinsically volatile. By 2012, Yahoo! was in decline and needed to be revitalised as Google and Facebook were taking market share and advertising dollars from Yahoo! ${ }^{77}$ To reverse the decline, Mayer issued a decree banning employees from working at home and asserted that 'working side by side' at company headquarters would increase the quality of decisions and insights. ${ }^{78}$ Analysts took a more realistic view and declared that the back-to-work edict was a ploy to cull staff by dismissing anyone unwilling to return to a disciplinary regime bent on increasing the productivity and competitiveness of Yahoo $!^{79}$ Mayer remained silent in the face of criticism that she was 'dissing working moms' by ordering

\footnotetext{
${ }^{73}$ Julie Kollewe, 'Anglo American Chief Cynthia Carroll to Step Down Next Year' The Guardian (online), 26 October $2012<$ http://www.theguardian.com/business/2012/oct/26/angloamerican-cynthia-carroll-step-down>.

${ }^{74}$ Ibid.

${ }^{75}$ Ibid.

${ }^{76}$ Ibid.

${ }^{77}$ Nikhil Kumar, 'She's Been at the Forefront of the Tech Revolution But Can Yahoo! CEO Marissa Mayer Really Get Away with Banning Her Staff from Working from Home?' The Independent (online), 2 March 2013 <http://www.independent.co.uk/news/people/news/shesbeen-at-the-forefront-of-the-tech-revolution-but-can-yahoo-ceo-marissa-mayer-really-getaway-8517490.html>.

${ }^{78}$ Jonathan Brown, 'A World Wide Web of Communication - But Yahoo! Tells Its Staff to Get Back in the Office' The Independent (online), 27 February $2013<\mathrm{http}: / /$ www.independent. co.uk/news/world/americas/a-world-wide-web-of-communication-but-yahoo-tells-its-staff-toget-back-in-the-office-8512141.html>.

${ }^{79}$ Ibid.
} 
them back to the office. ${ }^{80}$ Part of her silence is explicable by the fact that Mayer had a nursery next to the executive suite to house her infant child ${ }^{81}$ She had also built an estimated fortune of $\$ 300$ million. ${ }^{82}$

Moral homilies about Mayer's behaviour must not distract attention from the profit-making institutional forces that shaped her conduct. The objective and coercive institutions and social structures that dictated the pattern of Morphet, Carroll and Mayer's actions need illuminating. The way the social relations of business enmesh its agents and force them to execute its will must colour our judgment of those at the commanding heights of the economy. As Roberts notes, when the manager of a large firm confronts the decision to sack workers in order to restore profitability and stave off eventual liquidation, the 'compulsion of a ruthless systemic logic' transcends any personal misgivings ${ }^{83}$ The female head of a large enterprise can avoid slashing the workforce by resigning, but this would kill a corporate career for no discernible benefit as she would correctly surmise that, if she faltered, somebody else would be compelled to wield the knife. ${ }^{84}$

The inner logic of a market economy compels entrepreneurs of whatever gender to focus on maximising profits. This line of argument is endorsed by both left and right wing thinkers. The law-and-economics school, guided by the axioms of neo-classical economics, avers that efficiency considerations dictate that the control of the modern corporation must be exclusively allocated to shareholders because, otherwise, 'people who did not receive the marginal gains would be influencing corporate discretion, and the influence would not maximize the wealth of the participants as a group ${ }^{85}$ Individuals acting on the basis of optimising their marginal productivity and self-interest chime with the marketbased compulsion to maximise profits. To the end of maximising profits, the need is to appoint people who have a high skill set and 'regard dissent as a duty and that have a good fight now and then' ${ }^{86}$ The boxing analogy is apposite for the capital investment required by modern corporations for large scale projects and the risk associated with failure requires people with a strong nerve, and the

\footnotetext{
${ }^{80}$ Kumar, above n 77.

${ }^{81}$ Ibid.

${ }^{82}$ Ibid.

${ }^{83}$ Marcus Roberts, Analytical Marxism: A Critique (Verso, 1996) 25.

${ }^{84}$ Ibid.

${ }^{85}$ Frank H Easterbrook and Daniel R Fischel, The Economic Structure of Corporate Law (Harvard University Press, 1991) 69.

${ }^{86}$ Kent Greenfield, 'The Progressive Possibility of Corporate Law' (2013) 28(3) Australian Journal of Corporate Law 14.
} 
capacity to argue cogently their preferred strategic course for meeting earnings per share targets, and beating off competitors.

The above considerations suggest that it is pointless to allow the choice of top company managers to be guided by the candidate's membership of a particular gender or group. This is endorsed by Sally Wheeler, a prominent UK corporate law professor, who has observed that

an assertion that boards of directors do behave or will behave in a particular way unless the pool of potential members is widened is a claim unsupported by any robustly gathered empirical evidence. It relies instead on anecdotal recollection at best. ${ }^{87}$

A further point that needs affirming is that corporate law acts as an adjunct to the profit motive by imposing a legal duty on directors to serve shareholders' interests. Lord Wedderburn notes that when company law speaks of directors serving the 'interests of the company' this means 'the interests of profit'. ${ }^{88}$ As the arch conservative Richard Posner has cogently put it: 'a profession's characteristic modes of thought might have economic causes'. ${ }^{89}$ What Posner is alluding to is the intimate connection between law and economics and how the latter can influence legal concepts. The fundamental mandate of the corporation is as Bakan has succinctly put it to make money and eschew 'ethical and social concerns'. ${ }^{90}$

There is a studied silence from those promoting the cause of female empowerment at board level on the issue of law piloting directors to be concerned only for their shareholders and "not the community, or the workforce or whatever'. 91 In the contemporary world, as Berle and Means noted, shareholders have largely left the management of their capital to professional managers and directors. ${ }^{92}$ This group now administers large scale corporations. However, Pahl and Winkler's empirical study of corporate directors' highlights that this group is even more intent on constantly improving business profitability than the owners of capital who ceded administrative control over

\footnotetext{
${ }^{87}$ Wheeler, above n 21, 187.

88 Lord Wedderburn, 'The Legal Development of Corporate Responsibility: For Whom Will Corporate Managers Be Trustees?' in Klaus J Hopt and Günther Teubner (eds), Corporate Governance and Directors' Liabilities: Legal, Economic and Sociological Analyses on Corporate Social Responsibility (Walter de Gruyter \& Co, 1985) 3, 5-6.

${ }^{89}$ Richard A Posner, Overcoming Law (Harvard University Press, 1995) 35.

90 Bakan, above n 8, 38 .

${ }^{91}$ Ibid 35.

92 Hadden, above n 19, 133.
} 
big business to a managerial elite. ${ }^{93}$ In effect, every director is trapped in a Faustian bargain with the imperatives of capital no matter what their gender.

The goal of corporate law is the protection of property rights. Female directors and male directors are equally bound by the same legal rules that facilitate private profit. Every director, regardless of gender, pursues the aim of ensuring that the profit of an enterprise is channelled to shareholders. This axiom was cogently expressed by Bowen LJ in Hutton $v$ West Cork Railway Co, stating that:

The law does not say there are to be no cakes and ale, but there are to be no cakes and ale except such as are required for the benefit of the company...charity has no business to sit at Boards of directors qua charity. There is, however, a kind of charitable dealing which is for the interest of those who practice it, and to that extent...charity may sit at the Board, but for no other purpose. ${ }^{94}$

Bowen LJ was not seeking to preclude the company board from engaging in philanthropic gestures towards workers or anybody else, but any benefit had to also serve the shareholders. The company existed to provide profits for shareholders and any sum expended on workers that was not linked to this imperative breached directors' duties. Since 1980 the UK Companies Act has had a section stating a director must take account of the interests of employees. Corporate law scholars such as Parkinson and Sealy are scathing of the section, and its lack of substantive content, and thus window dressing nature. ${ }^{95}$ Over the years the section has been watered down to the point where Davies avers that employees have 'found it difficult to use the section offensively' ${ }^{96}$ The British academic, Lord Wedderburn, observed that directors' fiduciary duties were formulated to ensure that there was an analogy between the 'interests of the company' and the guaranteeing of profits to shareholders. ${ }^{97}$ Statute law in Australia is designed to supplement a profit-maximising society. Corcoran

\footnotetext{
${ }^{93}$ Ray E Pahl and J T Winkler, 'The Economic Elite: Theory and Practice' in Philip Stanworth and Anthony Giddens (eds), Elites and Power in British Society (Cambridge University Press, 1975) 102, 117-8.

${ }^{94}$ Hutton $v$ West Cork Railway Co (1883) 23 Ch D 654, 673. See also Parke v Daily News Ltd [1962] Ch 927.

95 Stephen Bottomley and Anthony Forsyth, 'The New Corporate Law: Corporate Social Responsibility and Employees' Interests' in Doreen McBarnet, Aurora Voiculescu and Tom Campbell (eds), The New Corporate Accountability: Corporate Social Responsibility and the Law (Cambridge University Press, 2007) 314.

${ }^{96}$ Paul L Davies, Gower and Davies: Principles of Modern Company Law (Sweet \& Maxwell, $8^{\text {th }}$ ed, 2008) 519.

${ }^{97}$ Lord Wedderburn, above n 87, 5-6.
} 
notes that the Australian Corporations Law 'actively discourages corporate concern for social welfare when social welfare must be purchased at a cost to profit maximisation'. ${ }^{98}$ The view that the modern corporation is a vehicle for maximising the profits of its shareholders was emphasised in 1970 by Milton Friedman, a famous liberal thinker and Nobel Prize winning economist. Friedman declared that

in a free-enterprise, private-property system, a corporate executive is an employee of the owners of the business. He has direct responsibility to his employers. That responsibility is to conduct the business in accordance with their desires which generally will be to make as much money as possible. ${ }^{99}$

For Friedman, corporate executives were acting for the social good when they were 'making maximum profits for stockholders'. ${ }^{100}$ The only responsibility of corporate leaders, declared Friedman, was 'to make as much money for their stockholders as possible'. ${ }^{101}$ With the law and market systematically operating to deny the corporate boardroom the capacity to cultivate civic or ethical concerns, it is unsurprising that both female and male directors are, as directors, constrained from pursuing goals that fail to meet a commercial standard. The law compels the upper strata of corporations of whatever gender to surrender to the logic of the market and its legal rules. Boosting the effectiveness of mechanisms that may lift the percentage of women directors provides only a partial insight into the machinations of the corporate entity.

An exploration of the logic of the modern corporation reveals that the purpose of capitalist production is profit for those who own the instruments of production. The individuals who manage and organise work must facilitate market imperatives and eschew any move to genuine equity. The objective place of individuals in a network of ownership relationships not only categorises their status, but is the key to how a hegemonic system of power works. The individual behaviour of shareholders and the directors who administer capital is shaped by 'external coercive laws'. ${ }^{102}$ The search for maximum profit is not a function of the personal idiosyncrasy of those owning and managing capital. Fundamentally, the quest for maximum profit is driven by the competitive individualism of the market. The competition for sales

\footnotetext{
${ }^{98}$ Suzanne Corcoran, 'The Corporation as Citizen and as Government: Social Responsibility and Corporate Morality' (1997) 2(1) Flinders Journal of Law Reform 53, 54.

${ }^{99}$ Milton Friedman, 'The Social Responsibility of Business is to Increase its Profits' The New York Times Magazine (New York), 13 September 1970, 176.

${ }^{100}$ Friedman, above n 9, 133.

${ }^{101}$ Ibid.

${ }^{102}$ Harvey, above n 54, 28.
} 
compels each producer to market a product of equal quality at less cost. ${ }^{103}$ The competition for sales compels every business to minimise costs and maximise profit. ${ }^{104}$

Notable thinkers such as Keynes, Ricardo, Smith and numerous other economists, understood the quest for profit to be the guiding principle of a market economy. ${ }^{105}$ Competitive advantage is only obtained by those who plough profits back into the company in order to expand faster than their competitors. ${ }^{106}$ The economic logic of the market holds sway regardless of an individual's gender. Every move by Morphet, Carroll and Mayer is only explicable when viewed through the conceptual lens of a competition for economic survival. To lose in the competitive battle is to ensure the eventual downfall of a business.

The trio of entrepreneurs represented by Morphet, Carroll and Mayer were, first and foremost, bearers and executors of economic laws, ready to sacrifice anything to stay in the game and be ahead of the competition. Their gender was irrelevant and played no role in how they developed their strategic plans. Ultimately, for directors to secure their positions, productivity rates have to rise and workers' wages increase at levels well below the increase in productivity or, better still, remain stagnant or decline in real terms. ${ }^{107}$ If successful, this policy is translated into higher profit rates. Morphet, Carroll and Mayer understood this and operated on this imperative. When Anglo American appointed Matt Chambers as Carroll's successor, his mantra to the market was that he was going to turbo-charge productivity rates. ${ }^{108}$ Carroll fell not because she was a woman, but because she was not driving up output per hour and lifting earnings per share. This also applied to Morphet. Mayer will be judged by the same efficiency and profitability yardstick and, if she fails to meet targets, she will be toppled. In April 2015, Mayer was on the cusp of losing her position. The share price and growth figures were languishing and unless there was a turnaround, it was being mooted that she would be forced to vacate her CEO

${ }^{103}$ David McNally, Global Slump: The Economics and Politics of Crisis and Resistance (The Merlin Press, 2011) 74.

104 Ibid.

105 Michael Bleaney, The Rise and Fall of Keynesian Economics: An Investigation of Its Contribution to Capitalist Development (Macmillan, 1985) 4, 17.

${ }^{106}$ McNally, above n 103, 74.

107 John Bellamy Foster and Fred Magdoff, The Great Financial Crisis: Causes and Consequences (Monthly Review Press, 2009) 129.

${ }^{108}$ Matt Chambers, 'New Anglo American CEO tells miners to raise bar on productivity' The

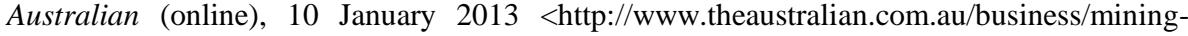
energy/industry-decades-behind-on-productivity-says-new-anglo-boss-miners-told-to-raisethe-bar/story-e6frg9df-1226550704199>. 
role at Yahoo! ${ }^{109}$ In September 2015, with the share price having fallen by a quarter in the past year Mayer was clinging on but was in deep trouble, and concern about whether Yahoo! would survive was being voiced. ${ }^{110}$ The lessons of corporate history are clear. The social structure of power wins every time against gender in corporate boardrooms and on the Stock Exchange.

\section{CONCLUSION}

This article has interrogated the view that regulatory mechanisms need to be more efficacious if gender diversity at the apex of the corporate form is to be optimised. The pluralist interpretation of how the inadequate representation of women on corporate boards could be addressed has been critiqued. This article has developed a different conceptual framework that has focused on the economic mechanisms of corporate capital. The article has gone beyond seeing more women on boards as a way forward to a more democratic society. In sum, this article has averred that the compulsive forces of capital accumulation in an environment of competitive individualism rule the corporation regardless of the gender composition of those at the commanding heights of the economy. It has pinpointed how both right and left wing economists are united in perceiving the modern corporation as a vehicle driven by the imperative to maximise profit. The pursuit of unlimited growth and profit is the motor force of the system. This means that little can be achieved by 'closing the gender gap' or boosting 'social responsibility'. Any slowdown in profitmaking threatens stagnation and the breakdown of the capitalist system. ${ }^{111}$ Every director, regardless of gender, must optimise capital accumulation and profit or face the liquidation of their company. Every director must constantly strive to lift productivity through technological advances and changes to the internal organisation of the business in order to cut costs and accrue higher profits than competitors. Lifting the participation of women on boards is a worthy cause but it is an objective that can mask the fact that a female director is fundamentally defined as a capitalist entrepreneur, and in this role is obliged to ensure the profitability of the company in order to continue in her prized position.

\footnotetext{
${ }^{109}$ Everett Rosenfeld, ‘Fmr. Yahoo [sic] CEO: Marissa Mayer May Have to Go' (15 April 2015) CNBC<http://www.cnbc.com/id/102589522>.

${ }^{110}$ Luke Kawa and Tracy Alloway, 'Yahoo [sic] Should Be Euthanised, CEO Marissa Mayer Grossly Overpaid: NYU Professor' Sydney Morning Herald (online), 10 September 2015 $<$ http://www.smh.com.au/business/media-and-marketing/yahoo-should-be-euthanised-ceomarissa-mayer-grossly-overpaid-nyu-professor-20150910-gjja43.html>.

${ }^{111}$ Henryk Grossman, The Law of Accumulation and Breakdown of the Capitalist System (Pluto Press, 1992) 126.
} 
Women company directors are part of the dominant class and far removed from the lives of the bulk of female employees. Putting more women in the boardroom is a liberal feminist cause that must be supported. Apart from anything else, when there are more women in the boardroom and the inner logic of the capitalist system remains unchanged, it sends a political message to the female workers left behind on the shopfloor that they cannot look for salvation from bourgeois women, and they must develop their own emancipatory ideology. They will see that raising female board numbers will not in itself facilitate rising profits, but even if this were the case, the real winner would be capitalist shareholders and the higher profits would come at the cost of added sweat from other working class women. Every director must squeeze the maximum labour from their workforce and be like a 'vampire that will not let go while there remains a single muscle, sinew or drop of blood to be exploited' ${ }^{112}$ Capital is indifferent to the gender of the vampire that sucks the blood of employees. All it cares about is recruiting those who can deliver superprofits and thus stay ahead in the competitive game. The watchword of the capitalist system is, as Marx noted: 'Accumulate, accumulate! That is the Moses and the prophets! ${ }^{113}$ Social justice demands that every progressive thinker support the campaign to increase female participation at the apex of the corporation whilst recognising that this will not result in the corporate leopard changing its spots.

\footnotetext{
112 Marx, above n 7, 416.

${ }^{113}$ Ibid 742.
} 